\title{
Photogrammetry with a Drone "DJI Phantom 2 Vision Plus": 3D Model of an Area Deformed by Neotectonics in the Venezuelan Andes
}

\author{
Riccardo Rocca \\ Repsol Exploration, Department of Basin Evaluations, Madrid, Spain
}

Email address:

riccardo.rocca@hotmail.com

To cite this article:

Riccardo Rocca. Photogrammetry with a Drone "DJI Phantom 2 Vision Plus": 3D Model of an Area Deformed by Neotectonics in the Venezuelan Andes. Earth Sciences. Vol. 6, No. 5, 2017, pp. 63-68. doi: 10.11648/j.earth.20170605.11

Received: July 24, 2017; Accepted: August 17, 2017; Published: September 4, 2017

\begin{abstract}
A commercial drone was used to acquire a series of images in an area in the Venezuelan Andes characterized by the deformation of a regional strike-slip fault. The digital model obtained by processing the images has allowed to obtain quantitative measurements of the fault displacement and to test geological concepts related to the structure evolution. The test has proven several benefits in applying the drone technology to support the classic geological field work.
\end{abstract}

Keywords: Drone, DJI, Phantom, Photogrammetry, Digital Model, Venezuelan Andes, Boconó Fault

\section{Introduction}

The availability of affordable commercial drones and dedicated software is making it possible to easily acquire a grid of images over an area and process them to obtain a digital model of the topography. This technology can be very useful when applied to the geological field work, where data are traditionally collected with the aim of reconstructing complex three dimensional geometries.

In order to test the benefits of this technology when applied to geology, a drone acquisition was planned in the Venezuelan Andes, in an area where the topography is clearly expressing the deformation induced by active tectonic. The area was thoroughly studied during the past decades by means of traditional field work and several papers were published describing its features and evolution, therefore a wealth of information was available as a useful reference for the flight planning and for the validation of the drone acquisition.

\section{Geological Background}

The Venezuelan Andes are characterized by the presence of a major tectonic lineament, the Boconó strike-slip fault (Figure 1), which is the result of the northward extrusion of the Maracaibo block as a consequence of the convergence between the Nazca and the South America plates (Figure 2) [1] [2]. The relative motion along this fault has displaced several landscape features like the "Los Zerpa" moraine system (Figure 3) which formed during the last glaciation in Pleistocene-Holocene age [3] [4] [5] [6]. Its northern tip crosses the Boconó fault and is displaced $100 \mathrm{~m}$ towards NE. 

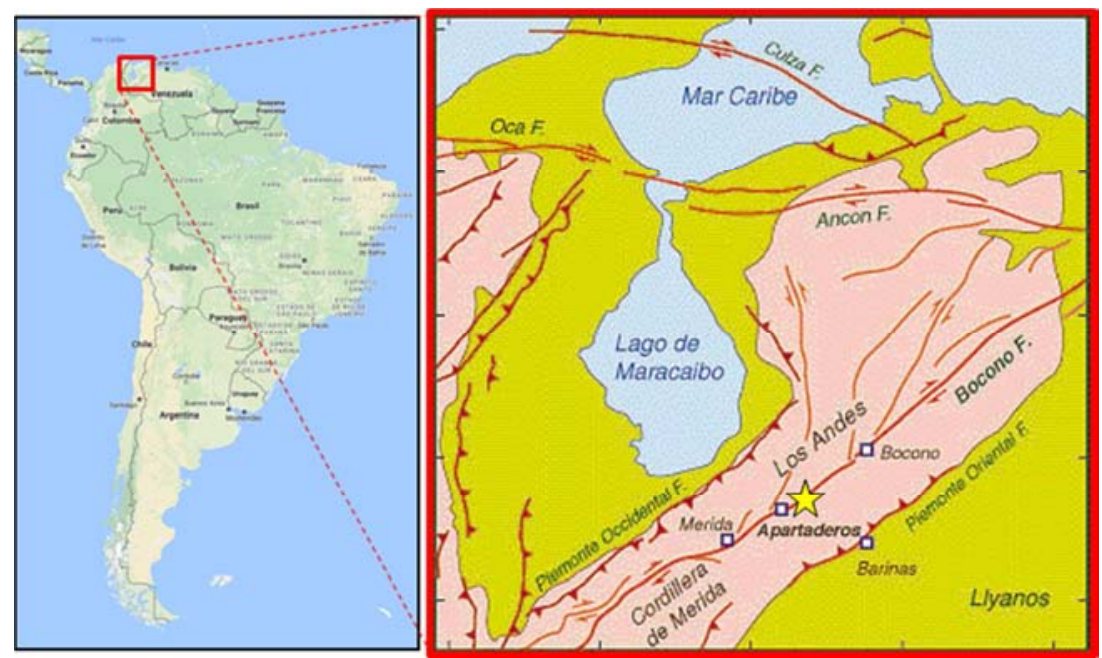

Figure 1. Geographic location of the study area (yellow star): 5 km north-east of the locality "Apartaderos", along the Boconó fault, in the Venezuelan Andes.

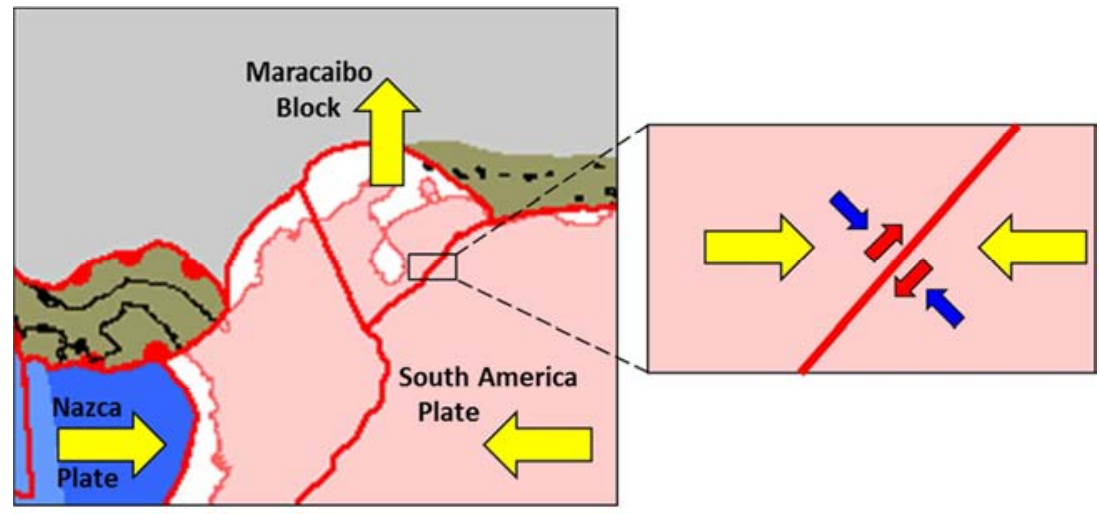

Figure 2. Tectonic setting of the Boconó fault: the strike slip movement along the fault is interpreted to be the result of the extrusion of the Maracaibo block, as a consequence of the convergence between the Nazca and the South America plates (image edited from [2]).

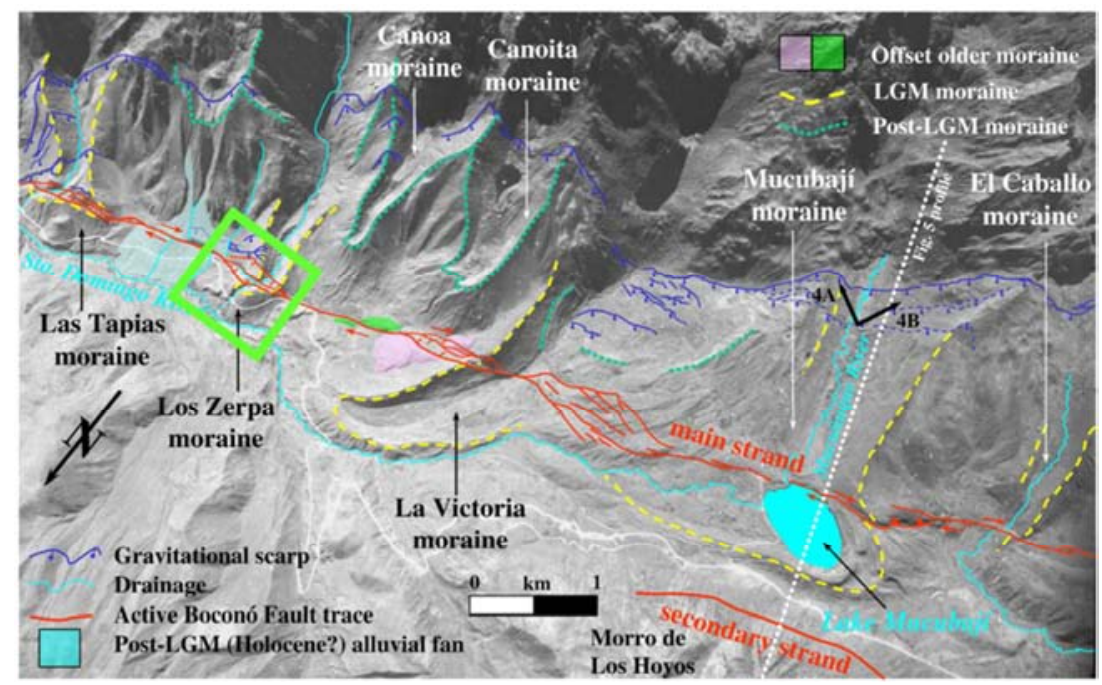

Figure 3. Location of the "Los Zerpa" moraine (green box) selected for the acquisition with the drone. It is one of the many topographic features (such as rivers and glacial moraines) that appear displaced by the trace of the Boconó fault (image edited from [5]).

\section{Moraine System Evolution}

A model for the moraine evolution was proposed by $\mathrm{C}$. Schubert in 1983 [7] and then confirmed by other authors more recently [8] [9], highlighting the interaction between the activity along the Bocono fault and the sedimentary processes in the moraine system (Figure 4). The model implies that the waters from the glacial valley were initially drained by a river that was flowing through the frontal part of the moraine (Figure 4.A, B, C). 
In a later stage, the movements along the Boconó fault opened a breach across the lateral moraine, the river was deviated to the right and started to flow through this new escape route. The original route through the frontal moraine was abandoned and is preserved nowadays as a dry incision.
The change in the drainage pattern caused the river to start eroding the sediments that were filling the valley. The level of the original filling is witnessed nowadays by the presence of two erosional terraces along the flanks of the moraine (Figure 4.D, E, F).

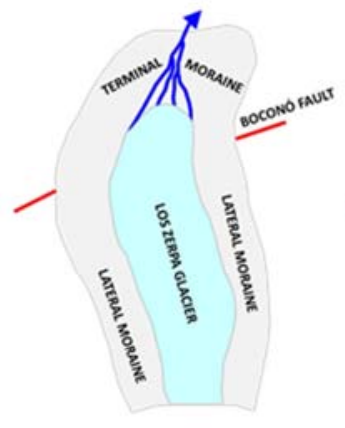

A) Glacier advance

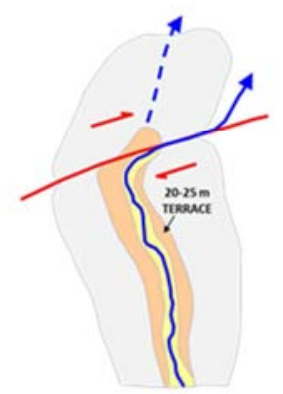

D) Boconó fault offset

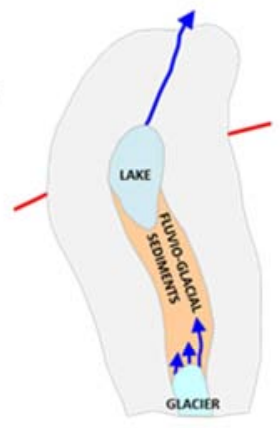

B) Glacier retreat

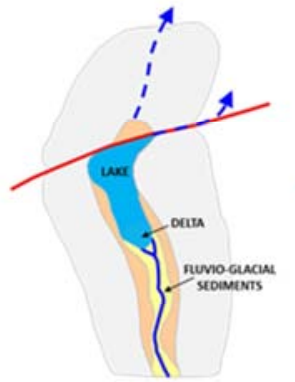

E) New sedimentary cycle

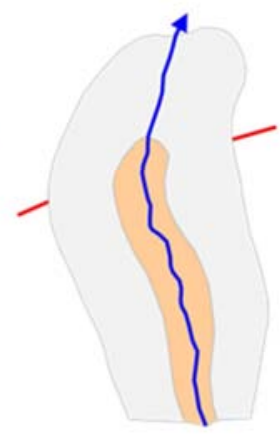

C) Fluvioglacial sedimentation

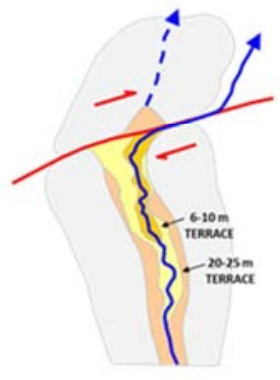

F) Present

day

Figure 4. Model of the evolution of the "Los Zerpa" moraine system according to C. Schubert 1983 (images edited from [7]).

\section{Acquisition and Preliminary Analysis of the Digital Model}

The acquisition was performed with a drone model "DJI Phantom 2 Vision Plus", acquiring about 300 images over an area of $400 \times 600 \mathrm{~m}$ (Figure 5).

The digital model was generated by processing the images with the software Pix4Dmapper.
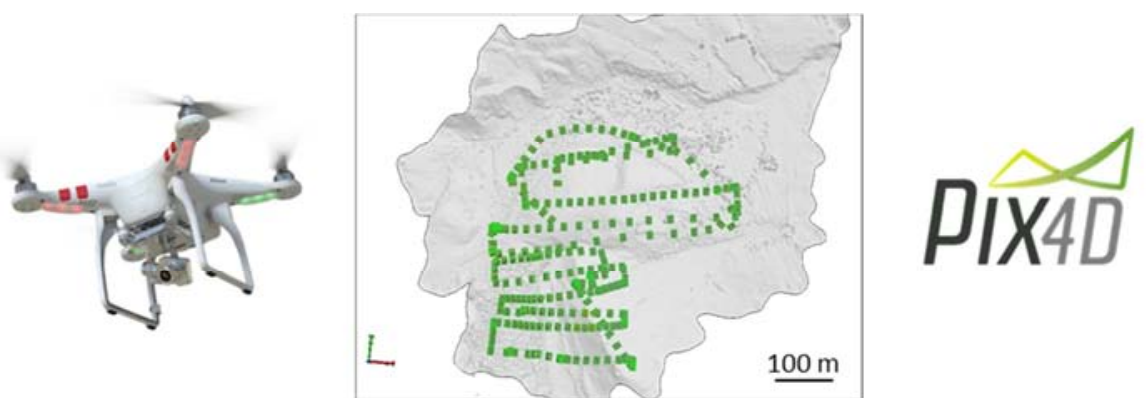

Figure 5. The drone "DJI Phantom 2 Vision Plus" that was used for the acquisition, the location of the images (green dots) acquired over the area of interest, and the Logo of the processing software Pix $4 D$.

The digital model generated after processing the images, allows identifying several geomorphologic features related to the interaction between the Boconó fault and the moraine deposits (Figure 6):

(1) tectonic scarps identifying the fault trace
(2) a $90^{\circ}$ sharp bend of the river running down the glacial valley, where it gets captured and deviated along the fault strike

(3) the $100 \mathrm{~m}$ dextral displacement of the lateral moraines and glacial valley as they cross the fault 
(4) two terraces witnessing past periods of fluvial infill within the glacial valley, later eroded when the fault activity opened a fluvial escape through the right lateral moraine

(5) the abandoned fluvial valley that used to drain the moraine system before it was breached by the fault

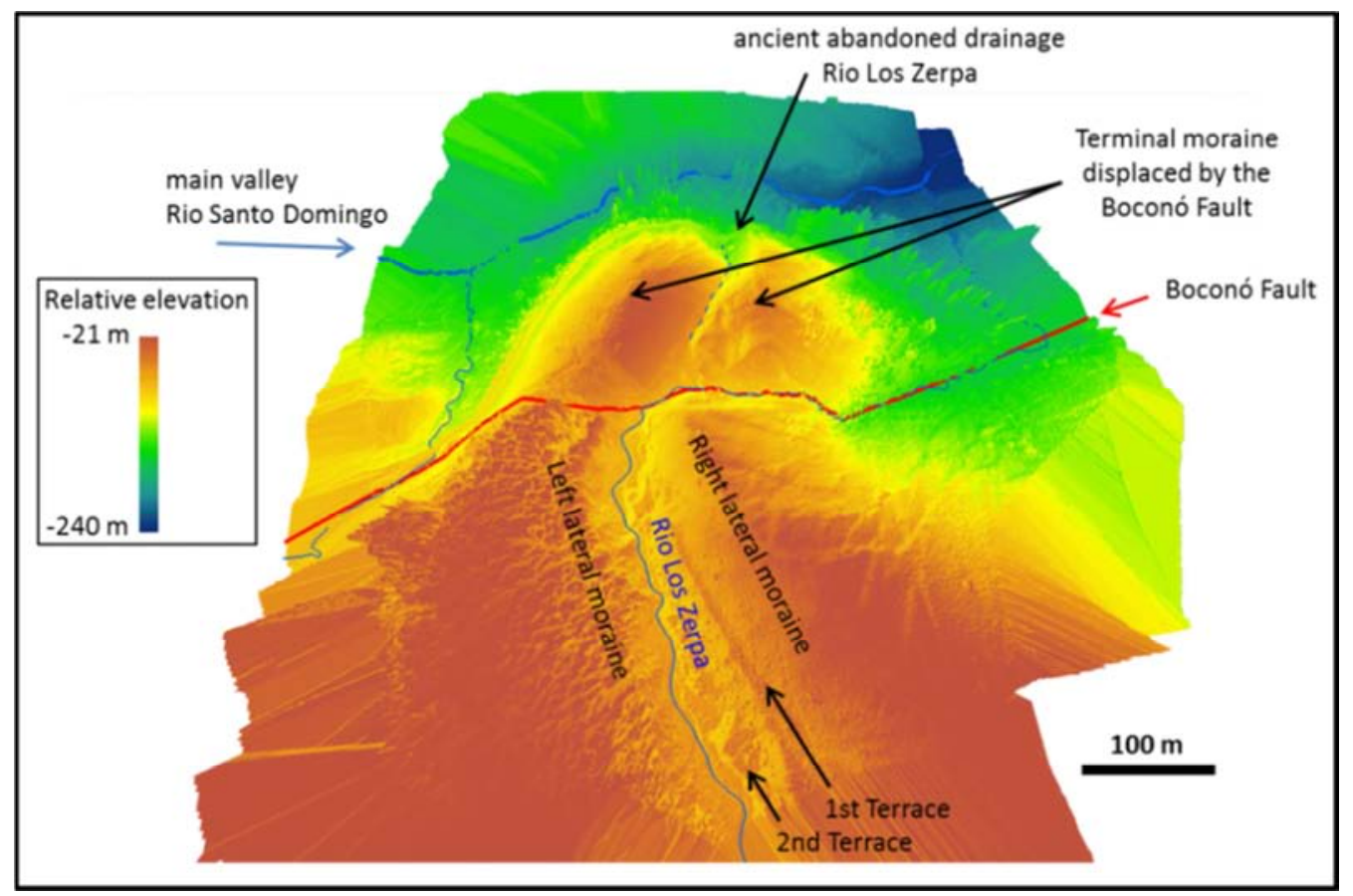

Figure 6. The digital model obtained after processing the images acquired with the drone. Several geomorphologic features can be identified that highlight the interaction between the Boconó fault and the moraine system.

\section{Modeling the Fault Displacement}

One practical application of the digital model is to perform quantitative measurements of the geological features. The following example describes the process implemented to measure the rate of displacement along the Boconó fault (Figure 7).

A) Initially, the fault trace is outlined by identifying specific features like scarps in the topography and sharp bends in the present day rivers drainage.

B) After drawing the geometry of the fault, its displacement becomes evident by observing the deviations in the present day drainage and the displacement in the topographic crests
C) Finally, a simple structural restoration is applied by aligning the displaced elements on either side of the fault: the corresponding portions of the moraine crests and the present day fluvial valley with the ancient abandoned drainage that incides the frontal moraine. The restoration allows measuring a $100 \mathrm{~m}$ displacement along the fault.

This displacement records the deformation of the moraine since the time when the glacier retreated and stopped remodeling and regenerating the moraine. Glaciers retreated in the late Pleistocene in this area of the Andes [7] [8] [9] [10], that is about 16000 years ago. Dividing $100 \mathrm{~m}$ by 16000 years yields an average shift along the Boconó fault of 6.25 $\mathrm{mm}$ per year, which is reasonably close to the present day shift of 7-10 mm per year measured by GPS [11] [12].
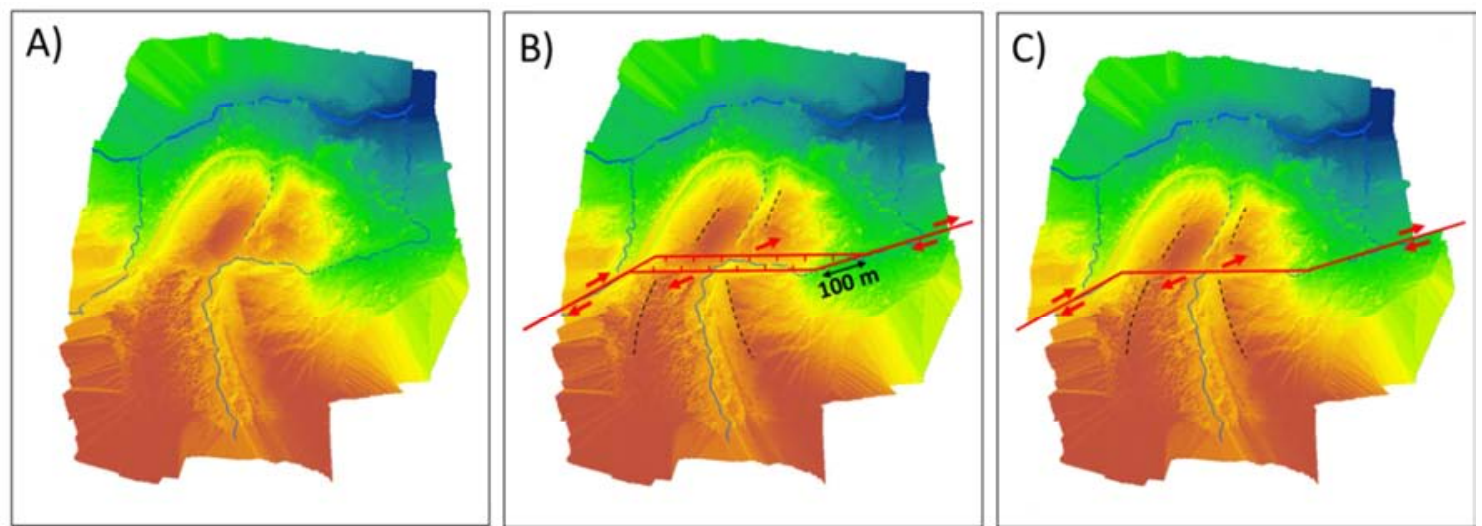

Figure 7. Structural restoration of the moraine system and quantification of the displacement along the Bocono fault (100 m). 


\section{Testing Schubert Model}

Another application of the digital model was to test the geometrical consistency of the evolution model described by C. Schubert [7].

For this purpose, the digital model was loaded in Arc Scene and combined with some geometrical elements: the cross sections across the upper part of the glacial valley and across the frontal moraine, the river profile, and the alluvial surfaces at present day (Figure 8.A).

The main objective of this test was to explain the origin of the incision in the frontal moraine. Supposing that it is an abandoned river bed, it is evident that it was not generated by the present day river because the geometrical reconstruction shows that its level is too deep to be able to reach and flow through that incision (Figure 8.B).

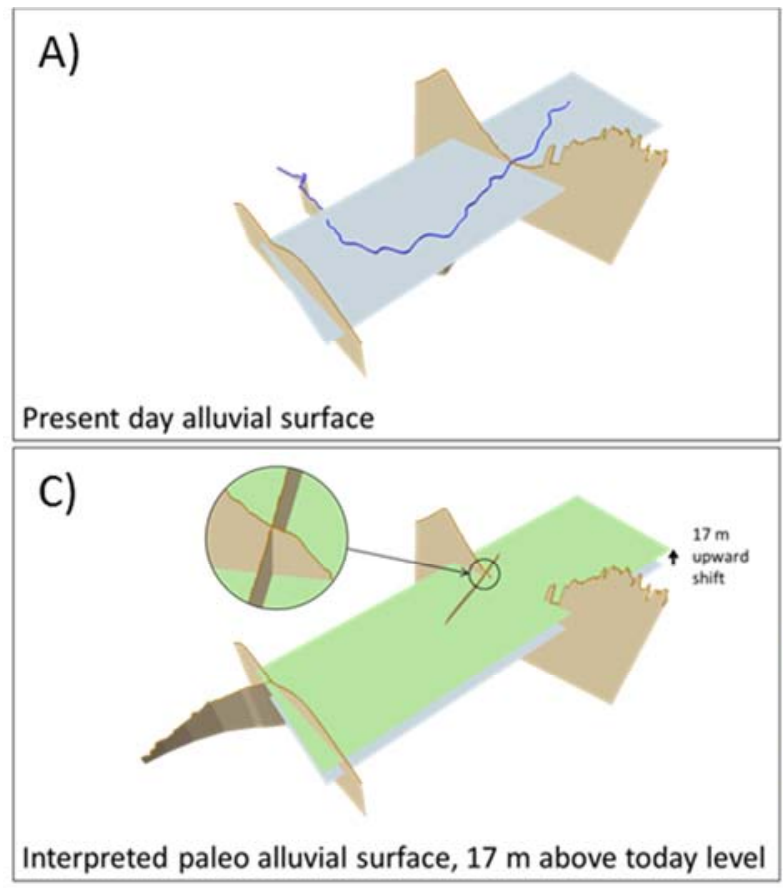

Figure 8. Testing the geometrical consistency of the evolution model described by C. Schubert (refer to the text for explanation).

\section{Conclusions}

This experience has proven several benefits in using a dronebased technology in the geological field work:

(a) the acquisition can be made in remote impervious areas with difficult access.

(b) maps can be acquired at low cost and high resolution (typically a few $\mathrm{cm}$ per pixel).

(c) 3D models are generated at true scale and can be used to measure distances, thicknesses and volumes.

(d) geological features can be observed from the most favorable point of view.

More specifically in this experience the digital model has allowed testing geological concepts in three dimensions in a much more effective way than with the classic representations of 2D maps and sections.
But the model indicates that the river was flowing at a higher level when the valley was filled with sediments in the initial stage of its evolution. These sediments were later eroded, but their original level is witnessed by the presence of two erosional terraces that are visible nowadays along the flanks of the valley.

A paleo alluvial surface was reconstructed by generating a plane parallel to the present day alluvial surface, but shifted 17 meters upwards until it intersects the marks of the upper terrace (figure 8.C). The frontal part of this plane reaches very precisely the height of the dry abandoned incision and confirms the theory that this was the initial route of the drainage flowing out of the glacial valley at a time when the valley was completely filled with sediments (Figure 8.D).

B)

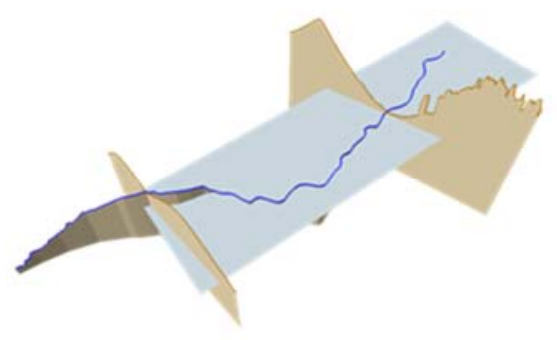

Unrealistic updip river flow

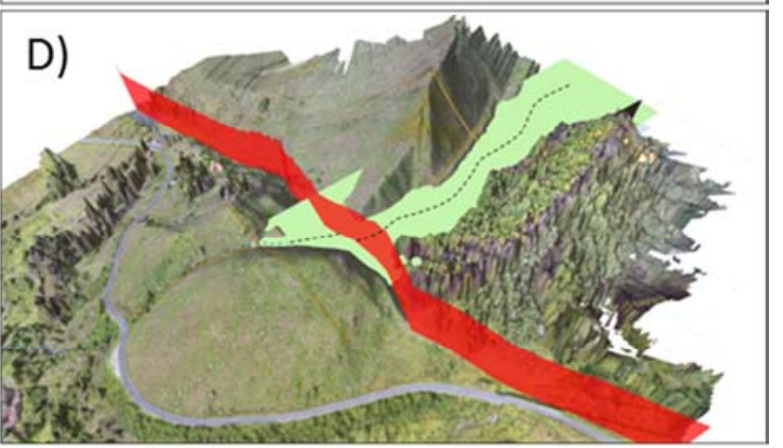

The continuous improvements and the affordability of both hardware and software invite to think of applying this technology widely in support of the classic geological field work.

\section{References}

[1] Backé Guillaume, Dhont Damien, Hervouët Yves (2006) Spatial and temporal relationships between compression, strike-slip and extension in the Central Venezuelan Andes: Clues for PlioQuaternary tectonic escape. Tectonophysics

[2] Dutch Steven (2009) Plate Tectonics and the Evolution of Central America and the Caribbean. University of Wisconsin https://www.uwgb.edu/dutchs/CostaRica2008/CR-PT.HTM

[3] Rod Emile (1955) Strike-slip faults in Northern Venezuela. Bulletin of the American Association of Petroleum Geologists 
[4] Audemard Frank, Beck Christian, Carrillo Eduardo, Castilla Raymi, Cousin Michel, Jouanne François, Melo Luis, Villemin Thierry (2002) Stability of Quaternary morainic complexes cut by the Boconó fault, Mérida Andes, Western Venezuela. 5th International Symposium on Andean Geodynamics

[5] Audemard Franck A., Beck Christian, Carrillo Eduardo (2010) Deep-seated gravitational slope deformations along the active Boconó Fault in the central portion of the Mérida Andes, western Venezuela. Geomorphology

[6] Costa, C., Audemard, F., Audin, L., Benavente, C. (2010) Geomorphology as a Tool for Analysis of Seismogenic Sources in Latin America and the Caribbean. Natural Hazards and Human-Exacerbated Disasters in Latin America

[7] Schubert C. (1983) Tectonics and Sedimentation: an example from the Mérida Andes (Venezuela). Acta Geologica Hispanica

[8] Carrillo Eduardo, Audemard Franck, Beck Christian, Cousin Michel (2002) Sedimentary disturbances in Late Quaternary fluvio-lacustrine deposits of the Los Zerpa moraine induced by the Boconó fault, Mérida Andes, Venezuela. 5th International Symposium on Andean Geodynamics
[9] Carrillo Eduardo, Audemard Franck A., Beck Christian, Villemin Thierry (2006) A Late Pleistocene-Holocene natural seismograph along the Bocono Fault (Merida Andes, Venezuela): the moraine-dammed Los Zerpa paleo-lake. Bulletin de la Societe Geologique de France

[10] Steven G. Wesnousky, Reina Aranguren, Martin Rengifo, Lewis A. Owen, Marc W. Caffee, Madhav Krishna Murari, Omar J. Pérez (2012) Toward quantifying geomorphic rates of crustal displacement, landscape development, and the age of glaciation in the Venezuelan Andes. Geomorphology

[11] Perez Omar J., Bilham Roger, Bendick Rebecca, Velandia Jose R., Hernandez Napoleon, Moncayo Carlos, Hoyer Melvin, Kozuch Mike (2001) Velocity field across the southern Caribbean plate boundary and estimates of Caribbean/South-American plate motion using GPS geodesy 1994-2000. Geophysical Research Letters

[12] Pérez O. J., Bilham R., Sequera M., Molina L., Gavotti P., Codallo H., Moncayo C., Rodríguez C., Velandia R., Guzmán M., Molnar P. (2011) Campo de velocidades GPS en el occidente de Venezuela: componente lateral derecha asociada a la falla de Boconó y componente convergente perpendicular a los Andes. Interciencia 